\title{
Interactive comment on "Development of a versatile source apportionment analysis based on positive matrix factorization: a case study of the seasonal variation of organic aerosol sources in Estonia” by Athanasia Vlachou et al.
}

Athanasia Vlachou et al.

athanasia.vlachou@psi.ch

Received and published: 21 March 2019

The comment is uploaded in the form of a supplement.

Please also note the supplement to this comment:

https://www.atmos-chem-phys-discuss.net/acp-2018-1099/acp-2018-1099-AC1- 
2018.

ACPD

Interactive

comment

Printer-friendly version

Discussion paper 